22. Juniper, E. F., Frith, P. A., Dunnett, C., Cockroft, D. W., and Hargreave, F. E.: Reproducibility and comparison of responses to inhaled histamine and metacholine. Thorax, 33: 705 (1978).

23. Kattan, M., Keens, T. G., Mellis, C. M., and Levison, H.: The response to exercise in normal and asthmatic children. J. Pediatr., 92: 718 (1978).

24. Kawabori, I., Pierson, W. E., Conquest, L. L., and Bierman, C. W.: Incidence of exercise-induced asthma in children. J. Allergy Clin. Immunol., 58: 447 (1976).

25. Kerrebijn, K. F. and Neijens, H. J.: Measurement of the bronchial responsiveness in children. Progr. Respir. Res., 17: 143 (1981)

26. Kiviloog, J.: Bronchial reactivity to exercise and metacholine in bronchial asthma. Scand. J. Respir. Dis., 54: 347 (1973).

27. McFadden, E. R., Jr., Kiser, R. and DeGroot, W. J.: Acute bronchial asthma Relations between clinical and physiological manifestations. N. Eng. J. Med. 288: 221 (1973).

28. McNicol, K. N. and Williams, H. B.: Spectrum of asthma in children. I. clinical and physiological components. Br. Med. J., 4: 7 (1973).

29. Mellis, C. M., Kattan, M., Keens, T. G. and Levison, H.: Comparative study of histamine and exercise challenge in asthmatic children. Am. Rev. Respir. Dis., 117: 911 (1978).

30. Nadel, J. A. and Tierney, D. F.: Effect of a previous deep inspiration on airway resistance in man. J. Appl. Physiol., 16: 717 (1961).

31. O'Byrne, P. M., Ryan G., Morris, M., McCormack, D., Jones, N. L., Morse, J. L. C., and Hargreave, F. E.: Asthma induced by cold air and its relation to nonspecific bronchial responsiveness to metacholine. Am. Rev. Respir Dis., 125: 281 (1982)

32. O'Cain, C. F., Dowling, N. B., Slutsky, A. S., Hensley, M. J., Strohl, K. P. McFadden, E. R., Jr., and Ingram, R. H., Jr.: Airway effects of respiratory heat loss in normal subjects. J. Appl. Physiol.: Respirat. Environ. Exercise Physiol., 49: 875 (1980).

33. Pavia, D., Thomson, M. L., Clarke, S. W., and Shannon, H. S.: Effect of lung function and mode of inhalation on penetration of aerosol into the human lung. Thorax, 32: 194 (1977).

34. Polgar, G. and Promadhat, V.: Pulmonary Function Testing in Children: Techniques and Standards. (W. B. Saunders, Philadelphia-London-Toronto 1971).

35. Ryan, G., Dolovich, M. B., Eng, P., Obminski, G., Cockroft, D. W., Juniper, E., Hargreave, F. E., and Newhouse, M. T.: Standardization of inhalation provocation tests: influence of nebulizer output, particle size and method of inhalation. J. Allergy. Clin. Immunol., 67: 156 (1981).

36. Silverman, M. and Anderson, S. D.: Standardization of exercise tests in asthmatic children. Arch. Dis. Child., 47: 882 (1972).

37. Simonssen, B. G., Jacobs, F. M., and Nadel, J. A.: Role of autonomic nervous system and the cough reflex in the increased responsiveness of airways in patients with obstructive airway disease. J. Clin. Invest., 46: 1812 (1967).

38. Solymar, L., Aronsson, P. H., Bake, B., and Bjure, J.: Nitrogen single breath test, flow-volume curves and spirometry in healthy children, 7-18 years of age. Europ. J. Resp. Dis., 61: 275 (1980).

39. Strauss, R. H., McFadden, E. R., Jr., Ingram, R. H., Jr., and Jaeger, J. J.: Enhancement of exercise-induced asthma by cold air. N. Engl. J. Med., 297: 743 (1977).

40. Strauss, R. H., McFadden, E. R., Jr., Ingram, R. H., Jr., Deal, E. C., Jr., and Jaeger, J. J.: Influence of heat and humidity on the airway obstruction induced by exercise in asthma. J. Clin. Invest., 61: 433 (1978).

41. Swift, D. L.: Generation and respiratory deposition of therapeutic aerosols. Am. Rev. Respir. Dis., 122 (No. 5, part 2): 71 (1980).

42. Taussig, L. M., Chernick, V., Wood, R., Farrell, P., Mellins, R. B., and members of the conference committee: Standardization of lung function testing in children. Proceedings and recommendations of the GAP Conference Committee, Cystic Fibrosis Foundation. J. Pediatr., 97: 668 (1980)

43. Zach, M. S., Schnall, R. P., and Landau, L. I.: Upper and lower airway hyperreactivity in recurrent croup. Am. Rev. Respir. Dis., 121:979 (1980).

44. Zapletal, A., Motoyama, E. K., Gibson, L. E., and Bouhuys, A.: Pulmonary mechanics in asthma and cystic fibrosis. Pediatrics, 48: 64 (1971)

45. Zapletal, A., Samanek, M., and Paul, T.: Upstream and total airway conductance in children and adolescents. Bull. Europ. Physiopathol. Respir., 18: 31 (1982).

46. This work was presented in part in a poster symposium at the Annual Meeting of the American Thoracic Society, Kansas City, May 1983.

47. Visiting professor on sabbatical leave 1982; supported in part by the Bundesministerium für Wissenschaft und Forschung, Austria

48. Requests for reprints should be addressed to: Dozent Dr. Med. Maximilian Zach, Universitäts Kinderklinik, Auenbruggerplatz 30, A-8036 Graz, Austria.

49. Received for publication July 18,1983

50. Accepted for publication November $29,1983$.

\title{
Human IgG Antibodies to Carbohydrate and Protein Antigens in Mouse Protection Tests with Group B Streptococci
}

\author{
KAREN K. CHRISTENSEN, ${ }^{(39)}$ POUL CHRISTENSEN, GABRIEL DUC, WALTER H. HITZIG, \\ VIVEKA LINDEN, BEAT MÜLLER, AND REINHARD A. SEGER \\ Departments of Obstetrics and Gynecology and Medical Microbiology, University Hospital, Lund, Sweden and \\ Department of Pediatrics, Divisions of Hematology-Immunology and Neonatology, University of Zürich,
} Zürich, Switzerland [G.D., W.H.H., B.M., R.A.S.]

\section{Summary}

The protective effect of four commercial human gammaglobulin batches (I-IV) in mice was studied using six different strains of group B streptococci (GBS): types Ia; Ib; II, R-protein negative (R-); II, R+; III, R-; and III, R+. Each mouse received $1.0 \mathrm{ml}$ gammaglobulin and $0.5 \mathrm{ml}$ bacteria, $10^{6}-10^{8}$ colony forming units (CFU). There was a close correlation between antibody levels measured by the use of radiolabeled protein $A$ and the mouseprotective effect of the gamma-globulins. The mouse-protection tests demonstrated that batch I protected against GBS types Ia and III, R- at low concentration (65 mg/ $\mathrm{kg}$ mouse weight), against type Ib at medium ( $260 \mathrm{mg} / \mathrm{kg}$ ) and against type III, $\mathrm{R}+$ at high concentration. Batch IV protected against types Ia and Ib, although the doses were four times higher than those in batch
I, but did not protect against type III, $R+$. There was no mouse protection by any of the batches against type II.

Antibody levels against $I b c$ and $R$, protein antigens, were substantially lower in batch IV. Because the results of these mouse-protection studies indicate the importance of such antibodies against protein antigens, batches I-III might be more useful for therapy of neonatal GBS-septicemia.

\section{Abbreviations}

ELISA, enzyme-linked immunosorbent assay

GBS, group B streptococci

CFU, colony forming units

cpm, counts per minute 
GBS are a major cause of systemic infections in newborn infants, with a case fatality rate of $20-50 \%$ and a frequency. of neurologic sequelae of about $30 \%$ in infants with meningitis $(6$, $10,14,17)$. The disease seems to be correlated with a relative deficiency of maternal antibodies to GBS-type antigens $(2,5,16$, $25,37)$. For this reason, attention has been focused on immuneprophylaxis of the disease using vaccination (1) and administration of specific IgG antibodies to pregnant women and/or their infants.

GBS are divided into five types (Ia, Ib, Ic, II, and III) on the basis of mouse-protection tests $(19,20,36)$. Type Ic shares the Ia carbohydrate antigen with type Ia and the Ibc protein with type $\mathrm{Ib}$, whereas the other four types are characterized by unique carbohydrate antigens (36). Antibodies against each of these antigens protect mice from infection with GBS carrying the respective antigen. Recently, Linden (22) demonstrated that antibodies to another antigen, R-protein, protected mice against infection with type II strains carrying this structure (22). Rprotein, which can also be detected within groups A, C, G and $\mathrm{L}$ streptococci (22), had been hitherto considered to be of no importance with regard to the virulence of GBS and, therefore, has been the subject of only a few studies.

A recent study indicated that a majority of mothers of GBSinfected infants are poor responders to bacterial carbohydrate antigens (7). One study on genetic markers of human $\mathrm{IgG}(\mathrm{Gm}$ allotypes) suggested that this relative deficiency might have a genetic basis (15); thus, the prospects of giving successful prophylactic treatment by vaccination appear to be rather slim. On the other hand, a number of studies have been published concerning the protective effect of gammaglobulin preparations in experimental GBS-infections. Three animal species have been used: chicken embryos (38), neonatal rats $(11,12,29)$ and mice $(3,13,34)$. Most interest has been focused on carbohydrate antigens, in particular type III antigen $(3,11,12,13,29)$, whereas few studies concerning types Ia, Ib and II have been reported $(34,38)$. With one exception (3), the studies showed a protective effect of gammaglobulin $(11,12,13,29,34,38)$. Data concerning the Ibc protein and R-protein are not yet available.

Beneficial effects of the administration of gammaglobulin in newborn infants were reported in a non-controlled study (31). The present paper concerns the protective effect on mice of four different gammaglobulin batches, using six different GBS strains. The results indicate differences between the batches that might be attributable to a varying content of antibodies to GBS antigens, in particular protein antigens.

\section{MATERIALS AND METHODS}

Gammaglobulin batches. The following three batches of gammaglobulin (Sandoglobulin, for intravenous administration) (31) were kindly supplied by Sandoz Produkte AG (Basel): batch no. I (2.361.002.0), no. II (0.361.002.0), and no. III (2.361.800.0). The preparations were supplied lyophilized and dissolved in the accompanying solvent (isotonic saline) to a stock concentration of $82.5 \mathrm{~g} / \mathrm{l}$. Further dilutions were prepared in saline.

Gammaglobulin Kabi, $165 \mathrm{~g} / \mathrm{l}$, was purchased from AB Kabi (Stockholm) (batch no. IV, 77367, for intramuscular use). Further dilutions were prepared in saline. The IgA content in the four batches was quantitated using electroimmunoassay with specific antiserum against IgA (21).

Mouse-protection tests. The following GBS strains isolated from blood or cerebrospinal fluid specimens from infants with neonatal septicemia/meningitis were used: type Ia, strain no. W25260; type Ib, strain no. 207; type II, R-protein negative (II, $\mathrm{R}-$ ), strain no. W25121; type II, R-protein positive (II, R+), strain no. 02038; type III, R-, strain no. W25062; and type III, $\mathrm{R}+$, strain no. D052. The strains were grouped and typed as described previously (4). The six mothers of the GBS-infected infants, from whom the strains were isolated, had low serum levels of IgG antibodies against the type of GBS infecting their infants.
Inocula of the strains for mouse-protection tests were prepared as described for group A streptococci by Sramék (33), i.e., the bacteria in $\log$ phase were frozen at $-80^{\circ} \mathrm{C}$ until use. The mouseprotection tests were performed as described previously (24). Female adult NMRI mice (weight, $18-20 \mathrm{~g}$ ) were purchased from Anticimex (Stockholm). The bacteria $(0.5 \mathrm{ml})$ and gammaglobulin $(1.0 \mathrm{ml})$ were injected intraperitoneally using a separate syringe for each preparation. The gammaglobulin was injected immediately before the bacteria. The animals were observed for $96 \mathrm{~h}$ after challenge.

Before testing of the protective effect of the gammaglobulin preparations, the amount of bacteria needed to kill at least five out of 10 mice was titrated; it was found essential to use a minimal dose of bacteria because the protective effect of gammaglobulin decreased rapidly with increasing dose of bacteria.

Control groups of mice received saline instead of gammaglobulin. Fisher's exact test was used in the statistical analysis of the results.

Quantitation of anti-GBS antibodies. Quantitation of antibodies against whole bacteria of types Ia, Ib, II, and III GBS was performed using $\left[{ }^{125} \mathrm{I}\right]$-labeled protein A of Staphylococcus aureus, as described previously (5). In brief, the preparations to be tested were absorbed with a GBS strain without type antigens (No. 848, kindly supplied by the State Serum Institute, Copenhagen) and the antibodies against surface antigens of the corresponding type were then quantitated using radiolabeled protein A. Protein A binds to the Fc-part of human IgG1, 2 and 4 (18). In some experiments, anti-human IgG3 serum (kindly supplied by Dr. A. Grubb, Malmö General Hospital, Sweden) was added, as described previously (25), in order to investigate the gammaglobulins with regard to antibodies to type II GBS belonging to the human subclass IgG3.

In order to estimate antibodies against type $\mathrm{Ib}$ carbohydrate antigen, the gammaglobulin batches were absorbed with strain No. 848 and the antibodies against trypsinized $\mathrm{Ib}$ were then quantitated. Trypsin treatment, which was performed as previously described (5), removes the Ibc protein $(20,36)$. For quantitation of antibodies against the Ibc protein, the gammaglobulin batches were absorbed with trypsinized Ib GBS as described previously (5), followed by quantitation of antibodies against untrypsinized type Ib GBS. Antibodies to R-protein were determined as previously described, using protein A (25).

Two human sera, $\mathrm{L}$ and $\mathrm{H}$, were used throughout the studies to compare with the gammaglobulin batches. These sera represented "low" (L) and "high" (H) levels for all GBS-type antigens, as judged by tests on sera from pregnant GBS carriers giving birth to healthy infants $(6,8)$.

All tests were performed with gammaglobulin at a concentration of $10.3 \mathrm{~g} / \mathrm{l}$, corresponding to the level in human serum. The tests were performed in duplicate and the results are expressed in cpm. The difference between the duplicates did not exceed $10 \%$ of their mean value in any case. The background of the tests did not exceed $100 \mathrm{cpm}$, as tested with rabbit preimmune serum.

IgG antibodies to type III, R- GBS in the gammaglobulin batches were also determined, using ELISA. Before testing, the preparations were absorbed with strain 848 . The procedure for quantitation of antibodies in the absorbed batches followed the method described by Polin et al. (28). Type II GBS (strain No. W25062) was pepsin-treated in order to remove surface protein (28) and used for coating of the microtitre plates. Monospecific antihuman IgG-alkaline phosphatase conjugates were purchased from Orion Diagnostics AB (Trosa, Sweden). Results were determined photometrically at $405 \mathrm{~nm}$ using a Titertec Multiscan (Flow Laboratories, Solna, Sweden). Titres were expressed as the absorbance value of the respective preparation tested.

\section{RESULTS}

The antibody levels in the four gammaglobulin batches were compared with the antibody content in two human sera ( $\mathrm{H}$ and 
L), using radiolabeled protein A. All batches contained greater amounts of antibody to whole type Ia GBS than serum $\mathrm{H}$ (Table 1). Batch I contained more antibodies to type Ia than did batch IV (2070 and $1770 \mathrm{cpm}$, respectively). Batches I, II, and III gave intermediate values for antibodies to whole-type Ib GBS, whereas batch IV promoted an uptake of radioactivity corresponding to serum L. All four batches were remarkably low in antibodies against type II, R- GBS, only about $200 \mathrm{cpm}$ above serum L. The batches showed high levels of antibodies to type III, RGBS, with batch I showing $200 \mathrm{cpm}$ more than the other batches. Using the ELISA technique, it was also not possible to demonstrate any differences with respect to antibodies against pepsinized type III, R- GBS (Fig. 1).

In order to test the possibility that the anti-type II antibodies in the gammaglobulin batches not detectable by protein $\mathrm{A}$ belonged to the IgG3 subclass, a specific rabbit anti-IgG3 serum was added to the test system for anti-type II and anti-Ia antibodies. Only a slight increase (5-10\%) in binding of protein A was observed with the four batches.

Quantitation of antibodies to Ibc-protein and R-protein using radiolabeled protein $\mathrm{A}$ are also given in Table 1. Batch IV contained only $50 \%$ of the antibodies to Ibc-protein found in batches I, II, and III. The level of antibodies to R-protein was also lower, about $30 \%$, in batch IV than in the other batches.

Twofold dilutions of the four batches, ranging from 82.5-1.3 $\mathrm{g} / \mathrm{l}$, were tested for capacity to protect mice from infection with type III, R- GBS (Table 2). Each dilution was given to 10 mice, $1 \mathrm{ml}$ intraperitoneally/mouse, immediately before $10^{7} \mathrm{CFU}$ of the test strain. Compared with 20 control mice, of which 19 died, batch I afforded significant protection at a concentration of 1.3 $\mathrm{g} / \mathrm{l}$, corresponding to $1.3 \mathrm{mg} / \mathrm{mouse}$. Batches II and III afforded protection at a concentration of $2.6 \mathrm{~g} / \mathrm{l}$. Batch IV was protective at a concentration of $5.2 \mathrm{~g} / \mathrm{l}$.

Batches I and IV, $10 \mathrm{ml}$ of each at a concentration of $41.3 \mathrm{~g} /$ 1 , were absorbed with the pellet from 1 litre overnight culture of type III, R- GBS in Todd Hewitt broth at $37^{\circ} \mathrm{C}$. None of the batches gave significant protection against type III, R- GBS after the absorption. The amount of bacteria given to the mice was found to be important. When the dose of bacteria was raised to $5 \times 10^{7} \mathrm{CFU} /$ mouse batch IV gave no protection at a concentration of $82.5 \mathrm{~g} / \mathrm{l}$.

All four batches of gammaglobulin were tested for toxicity to mice by injecting groups of 10 mice with gammaglobulin, 82.5 $\mathrm{g} / \mathrm{l}$; none of the animals died. The capacity of batches I and IV to protect mice against GBS types Ia, Ib, II, R-, II, R+, and III, $\mathrm{R}+$ was also studied. The gammaglobulin batches were tested at the concentrations 41.3, 20.6, 5.2 and $1.3 \mathrm{~g} / \mathrm{l}$. Batch I protected at a concentration of $1.3 \mathrm{~g} / \mathrm{l}$ against type $\mathrm{Ia}$, whereas the lowest effective concentration of batch IV was $5.2 \mathrm{~g} / \mathrm{l}$ (Table 3). The corresponding concentrations of batches I and IV for protection against type $\mathrm{Ib}$ were 5.2 and $20.6 \mathrm{~g} / \mathrm{l}$. None of the concentrations of batch IV tested was effective against type III, $\mathrm{R}+$, in contrast to batch I which was protective at $20.6 \mathrm{~g} / \mathrm{l}$. None of the batches was protective against types II, $\mathrm{R}+$ and II, $\mathrm{R}-$.

Among the animals not protected by gammaglobulin against the various strains, heart blood was collected from 20 randomly selected mice; all specimens grew the type of GBS injected. Batches I, II and III contained $2 \%$ (w/w) IgA, whereas no IgA was detected in batch IV.

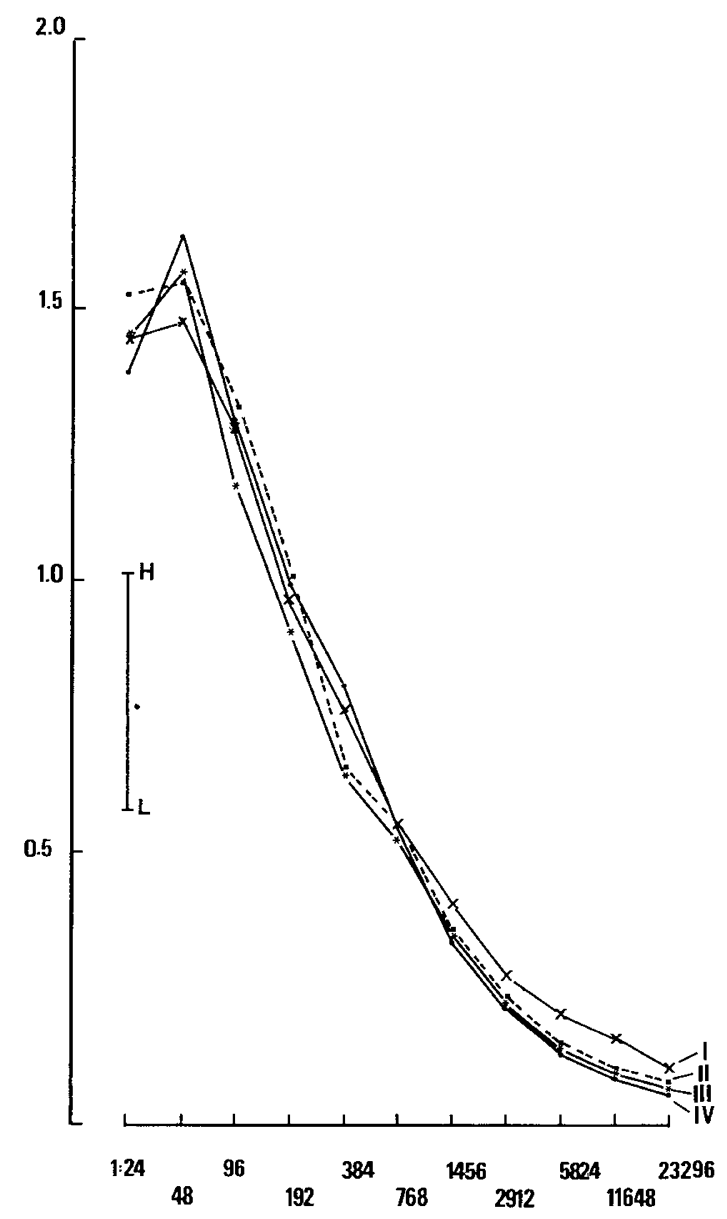

Fig. 1. Test of gammaglobulin batches I-IV for antibodies to pepsinized type III, R- group B streptococci (GBS) using enzyme-linked immunosorbent assay technique. Abscissa, dilution of respective batch tested. Ordinate, absorbance measured at $405 \mathrm{~nm}$ at end of test. $\mathrm{H}$ and $\mathrm{L}$ denote the values for two normal sera tested at dilution 1:24. The two sera represent the highest and lowest values, respectively, of sera from GBS-carriers giving birth to healthy infants, tested for antibodies to GBS, type III, $\mathrm{R}-$ using radiolabeled protein $\mathrm{A}$.

Table 1. Levels of type-specific antibodies to group B streptococci in four different gammaglobulin batches quantitated with radiolabeled protein $A$

Levels of antibodies (cpm) against

\begin{tabular}{|c|c|c|c|c|c|c|c|}
\hline \multirow[b]{2}{*}{ Batch } & \multirow[b]{2}{*}{ Type la } & \multicolumn{3}{|c|}{ Type Ib } & \multirow[b]{2}{*}{ Type II, R- } & \multirow[b]{2}{*}{ Type III, R- } & \multirow[b]{2}{*}{ R-protein } \\
\hline & & $\begin{array}{c}\text { Whole } \\
\text { bacteria }\end{array}$ & $\begin{array}{c}\text { Trypsinized } \\
\text { bacteria }\end{array}$ & Ibc-protein & & & \\
\hline I & 2070 & 1350 & 1110 & 1440 & 580 & 1640 & 3100 \\
\hline II & 1920 & 1240 & 1110 & 1550 & 610 & 1360 & 2910 \\
\hline III & 1820 & 1370 & 1080 & 1490 & 620 & 1420 & 2960 \\
\hline IV & 1770 & 940 & 840 & 620 & 650 & 1400 & 2160 \\
\hline Serum H & 1300 & 1760 & 1530 & 1810 & 1150 & 1070 & 2800 \\
\hline Serum L & 620 & 920 & 890 & 960 & 440 & 620 & 940 \\
\hline
\end{tabular}




\section{DISCUSSION}

The general picture that emerged from the quantitation of antibodies in the gammaglobulin batches by using radiolabeled protein A depicts a close correlation between the antibody levels and the results of the mouse protection tests. Batch I contained more antibodies against type Ia than batch IV (Table 1): accordingly, the animal protective concentrations were 1.3 and $5.2 \mathrm{~g} / \mathrm{l}$, respectively (Table 3 ). The protective levels of batches I and IV against type Ib GBS were 5.2 and $20.6 \mathrm{~g} / \mathrm{l}$, respectively, corresponding to antibody levels of 1350 and $940 \mathrm{cpm}$, respectively. All four batches showed remarkably low levels of antibodies against type II GBS carbohydrate antigen and none of the preparations were mouse-protective against this type. The antibody level against type III, R - was $1640 \mathrm{cpm}$ for batch I, vis-àvis 1360-1420 for batches II-IV. In mouse-protection tests the protective level of batch I was $1.3 \mathrm{~g} / \mathrm{l}$, in contrast to batches II and III which gave protection at $2.6 \mathrm{~g} / \mathrm{l}$ and batch IV with a protective level of $5.2 \mathrm{~g} / 1$ (Table 2). This demonstrated again a correlation between antibody levels and mouse protection. Most studies by others were concerned with the correlation between mouse protection and in vitro phagocytic assays $(11,12,13,29$, 34, 38).

Batch I showed a greater protective capacity for types Ia, Ib, III, $\mathrm{R}-$, and III, $\mathrm{R}+$ than did batch IV (Tables 2,3 ). Batches II

Table 2. The mouse-protective effect of four different gammaglobulin batches against GBS type III, $R-$ (strain No. $W 25062)^{*}$

\begin{tabular}{ccrrr}
\hline $\begin{array}{c}\text { Concen- } \\
\text { tration } \\
\text { of gamma } \\
\text { globulin }\end{array}$ & \multicolumn{4}{c}{ No. of mice surviving $(P$ value $) \dagger$ given batch } \\
\cline { 3 - 5 } used (g/l) & I & \multicolumn{1}{c}{ II } & \multicolumn{1}{c}{ III } & IV \\
\hline 82.5 & $10\left(<10^{-6}\right)$ & $8\left(<10^{-4}\right)$ & $9\left(<10^{-5}\right)$ & $10\left(<10^{-6}\right)$ \\
41.3 & $10\left(<10^{-6}\right)$ & $10\left(<10^{-6}\right)$ & $10\left(<10^{-6}\right)$ & $10\left(<10^{-6}\right)$ \\
20.6 & $10\left(<10^{-6}\right)$ & $10\left(<10^{-6}\right)$ & $9\left(<10^{-5}\right)$ & $10\left(<10^{-6}\right)$ \\
10.3 & $10\left(<10^{-6}\right)$ & $10\left(<10^{-6}\right)$ & $10\left(<10^{-6}\right)$ & $9\left(<10^{-5}\right)$ \\
5.2 & $10\left(<10^{-6}\right)$ & $10\left(<10^{-6}\right)$ & $10\left(<10^{-6}\right)$ & $8\left(<10^{-4}\right)$ \\
2.6 & $8\left(<10^{-4}\right)$ & $8\left(<10^{-4}\right)$ & $9\left(<10^{-5}\right)$ & $4(>0.05)$ \\
1.3 & $6(0.002)$ & $2(>0.05)$ & $2(>0.05)$ & $1(>0.05)$ \\
\hline
\end{tabular}

* Each mouse received $0.5 \mathrm{ml}$ bacteria containing $10^{7} \mathrm{CFU}$ and $1 \mathrm{ml}$ gammaglobulin (study groups) or $1 \mathrm{ml}$ saline (controls). The study groups consisted of 10 mice each. The control group consisted of 20 mice, of which only one survived.

$\uparrow$ Study group compared with the control group. and III were also more efficient in protecting against type III, $\mathrm{R}$ - than was batch IV (Table 2). Batches I, II, and III had higher levels of antibodies to the Ibc-protein and R-protein than batch IV (Table 1). On the other hand, the ELISA technique did not demonstrate any differences between the four batches with respect to antibodies against pepsinized type III, R- GBS. The main differences between batches I, II, and III, on the one hand, and batch IV, on the other, appear to concern antibodies to protein antigens and the content of $\operatorname{IgA}$ (not detectable in batch IV). The procedure used to remove IgA from batch IV may have resulted in the disappearance of IgG antibodies to protein antigens. Testing with gammaglobulin prepared in accordance with the manufacturing procedure for batches I-III indicated a normal distribution of subclasses as compared with human sera (32) whereas batch IV lacked IgG4 (V.A. Oxelius, personal communication). The details of the manufacturing procedures are unknown to us.

The differences between the protective effect of gammaglobulin preparations against type III, $\mathrm{R}-$ and type III, $\mathrm{R}+$ (Tables 2 and 3) may indicate that R-protein is of importance for the virulence of GBS in mice. We have previously found that antibodies to R-protein can be protective against type II, R+ (22) and that mothers of infants infected with $R+$ GBS stains have low levels of antibodies to R-protein (25). In clinical isolates from our district, $51 \%$ of type II strains and $86 \%$ of type III strains carried R-protein (26). Shigeoka et al. (30) described differences between type III strains with respect to resistance against opsonization with human antibodies. They also demonstrated that pepsin treatment of the resistant strains rendered the bacteria more susceptible to in vitro opsonization (30). The role of R-protein in this context remains to be elucidated.

There are still many important questions concerning the "translation" of mouse-protection tests to human GBS neonatal infections. GBS infection do not occur naturally in mice. Furthermore, the route of acquisition of GBS in neonatal septicemia is probably by the airways, which is an important difference from the mouse model where the bacteria are injected intraperitoneally. Little is known about the number of bacteria present in the blood stream during neonatal GBS septicemia. Probably, no amount of appropriate antibody will protect the human baby during the later stages of septicemia, and administration of gammaglobulin will only be a complement to antibiotics. This was illustrated by the finding that the Ig required for protection in the mouse model was highly dependent of the infecting dose of bacteria. The Ig required for protection is highly dependent of this dose. Only $5.2 \mathrm{mg}$ of batch IV protected mice against $10^{7}$ type III, R- GBS, whereas $82.5 \mathrm{mg}$ of the same batch did not

Table 3. Mouse-protective effect of two different gammaglobulin batches against group B streptococci (GBS) types Ia, Ib, II, R+ and III, $R+^{*}$

\begin{tabular}{|c|c|c|c|c|c|c|}
\hline \multicolumn{2}{|c|}{ Gammaglobulin } & \multicolumn{5}{|c|}{ No. of mice surviving (P value) $\dagger$ after challenge with GBS type } \\
\hline Batch & Concentration $(\mathrm{g} / \mathrm{l})$ & Ia & $\mathrm{Ib}$ & II, R- & II, R+ & III, R+ \\
\hline \multirow[t]{4}{*}{$I$} & 41.3 & $10(0.003)$ & $8(0.001)$ & $3(>0.05)$ & $7(>0.05)$ & $9(0.015)$ \\
\hline & 20.6 & $10(0.003)$ & $8(0.001)$ & $0(>0.05)$ & $6(>0.05)$ & $9(0.015)$ \\
\hline & 5.2 & $10(0.003)$ & $8(0.001)$ & $1(>0.05)$ & $5(>0.05)$ & $5(>0.05)$ \\
\hline & 1.3 & $7(0.036)$ & $5(>0.05)$ & $2(>0.05)$ & $6(>0.05)$ & $7(>0.05)$ \\
\hline \multirow[t]{4}{*}{ IV } & 41.3 & $10(0.003)$ & $6(0.020)$ & $2(>0.05)$ & $7(>0.05)$ & $4(>0.05)$ \\
\hline & 20.6 & $10(0.003)$ & $7(0.006)$ & $0(>0.05)$ & $5(>0.05)$ & $4(>0.05)$ \\
\hline & 5.2 & $9(0.026)$ & $4(>0.05)$ & $1(>0.05)$ & $2(>0.05)$ & $4(>0.05)$ \\
\hline & 1.3 & $3(>0.05)$ & $5(>0.05)$ & $0(>0.05)$ & $7(>0.05)$ & $7(>0.05)$ \\
\hline
\end{tabular}

No. of mice surviving/no. of $\quad 4 / 15 \quad 2 / 15 \quad 1 / 15 \quad 7 / 14 \quad 6 / 15$

mice challenged in control group

* Each mouse received $0.5 \mathrm{ml}$ bacteria and $1 \mathrm{ml}$ gammaglobulin (study groups) or $1 \mathrm{ml}$ saline (control groups). The challenge doses were for type Ia, $10^{6} \mathrm{CFU}$; type Ib, $10^{7} \mathrm{CFU}$; type II, R-, $10^{8} \mathrm{CFU}$; type II, R+, $10^{8} \mathrm{CFU}$; and type III, R+, $10^{8} \mathrm{CFU}$. The study groups consisted of 10 mice each.

$\dagger$ Study group compared with control group. 
protect against $5 \times 10^{7} \mathrm{CFU}$ of the same bacteria. It might be, therefore, misleading to calculate protective levels of gammaglobulin based on body weight only. The relationship between the amount of antibody and infecting dose might be more important. Studies on complement activation indicate that small amounts of specific antibodies coated on GBS type III activate the classical pathway whereas larger amounts recruite the alternative pathway (9).

The mouse-protection tests demonstrated that gammaglobulin batch I protected against type Ia and type III, R- GBS at a low concentration, $1.3 \mathrm{~g} / \mathrm{l}$, corresponding to $65 \mathrm{mg} / \mathrm{kg}$ mouse weight (Tables 2 and 3 ). The amount of batch I necessary to protect against type $\mathrm{Ib}$ was $5.2 \mathrm{~g} / \mathrm{l}$, or $260 \mathrm{mg} / \mathrm{kg}$, and for type III, $\mathrm{R}+$, $20.6 \mathrm{~g} / \mathrm{l}$ or $1030 \mathrm{mg} / \mathrm{kg}$. With all the above reservations for the translation to neonatal infants, it would seem that between $0.2-$ $3.0 \mathrm{~g}$ of batch I is sufficient to protect a newborn infant weighing $3000 \mathrm{~g}$ against infections with GBS types $\mathrm{Ia}, \mathrm{Ib}$ and III. On the other hand, neither batch I nor batch IV offered any mouse protection against type II, R- and II, R+ GBS.

The distribution of GBS types involved in neonatal septicemia/meningitis varies from one geographic region to another (27). In some American reports type III dominates (35) whereas the strains isolated in Sweden reflect the distribution of types in the urogenital tract of the parturients $(7,8)$. Among 41 strains isolated from cases of neonatal septicemia, eight belonged to type Ia, six to type Ib, eight to type II, and 19 to type III (23). We consider it important to include all serotypes in the planning of immunotherapy against neonatal GBS infection.

In conclusion, the present study demonstrates the importance of antibodies to protein antigens in preventing GBS infections in mice and confirms other reports indicating that gammaglobulin may play a role in the prevention and treatment of neonatal GBS infections. The possibility that antibodies to protein antigens might be lost during removal of IgA from human gammaglobulin batches needs further elucidation. Finally, the correlation found between mouse protection tests and antibody quantitation by radiolabeled protein $\mathrm{A}$ strengthens the clinical relevance of this method.

\section{REFERENCES AND NOTES}

1. Baker, C. J., Edwards, M. S., and Kasper, D. L.: Immunogenicity of polysaccharides from type III, group B Streptococcus. J. Clin. Invest., 61: 1107 (1978).

2. Baker, C. J. and Kasper, D. L.: Correlation of maternal antibody deficiency with susceptibility to neonatal group B streptococcal infection. N. Engl. J. Med., 294: 753 (1976).

3. Baltimore, R. S., Baker, C. J., and Kasper, D. L.: Antibody to group B Streptococcus type III in human sera measured by a mouse protection test. Infect. Immun., 32: 56 (1981).

4. Christensen, K. K. and Christensen, P.: Typing of group B streptococci from the throat and urogenital tract of females. Scand. J. Infect. Dis., 10: 209 (1978).

5. Christensen, K. K., Christensen P., Dahlander, K., Faxelius, G., Jacobson, B., and Svenningsen, N.: Quantitation of serum antibodies to surface antigens of group B streptococci, types Ia, Ib and III: low antibody levels in mothers of neonatally infected infants. Scand. J. Infect. Dis., I2: 105 (1980).

6. Christensen, K. K., Christensen, P., Hägerstrand, I., Lindén, V., Nordbring, F., and Svenningsen, N.: The clinical significance of group B streptococci. J. Perinat. Med., 10: 133 (1982).

7. Christensen, K. K., Christensen, P., Lindberg, A., and Lindén, V.: Mothers of infants with neonatal group B streptococcal septicemia are poor responders to bacterial carbohydrate antigens. Int. Arch. Allergy Appl. Immunol. 67: 7 (1982).

8. Christensen, K. K., Dahlander, K., Ekström, A., Svenningsen, N., and Christensen, P.: Colonization of newborns with group B streptococci: Relation to maternal urogenital carriage. Scand. J. Infect. Dis., 13: 23 (1981).

9. Edwards, M. S., Nicholson-Weller, A., Baker, C. J., and Kasper, D. L.: The role of specific antibody in alternative complement pathway-mediated opsonophagocytosis of type III, group B Streptococcus. J. Exp. Med., 151: 1275 (1980).

10. Eickhoff, T. C., Klein, J. O., Daly, A. K., Ingall, D., and Finland, M.: Neonatal sepsis and other infections due to group B beta-hemolytic streptococci. N. Engl. J. Med., 27l: 1221 (1964).

11. Fischer, G. W., Hunter, K. W., and Wilson, S. R.: Modified human immuneserum globulin for intravenous administration: in vitro opsonic activity and in vivo protection against group B streptococcal disease in suckling rats. Acta Paediatr. Scand., 71:639 (1982).
12. Fischer, G. W., Wilson, S. R., and Hunter, K. W.: Functional characteristics of a modified immunoglobulin preparation for intravenous administration: summary of studies of opsonic and protective activity against group B streptococci. J. Clin. Immunol., 2 (suppl.): 31 (1982).

13. Fleming, D. O.: Mouse protection assay for group B Streptococcus type III. Infect. Immun., 35: 240 (1982).

14. Franciosi, R. A., Knostman, J. D. and Zimmerman, R. A.: Group B streptococcal neonatal and infant infections. J. Pediatr., 82: 707 (1973).

15. Grubb, R., Christensen K. K., Christensen, P., and Lindén, V.: Association between maternal $\mathrm{Gm}$ allotype and neonatal septicemia with group B streptococci. J. Immunogenet., 9: 143 (1982).

16. Heming, V. G., Hall, R. T., Rhodes, P. G., Shigeoka, A. O. and Hill, H. R.: Assessment of group B streptococcal opsonins in human and rabbit serum by neutrophil chemiluminescence. J. Clin. Invest., 58: 1379 (1976).

17. Horn, K. A., Zimmerman, R. A., Knostman, J. D., and Meyer, W. T.: Neurological sequelae of group B streptococcal neonatal infection. Pediatrics, 53: 501 (1974).

18. Kronvall, G. and Williams, R. C. Jr.: Differences in anti-protein A activity among IgG subgroups. J. Immunol., 103: 828 (1969).

19. Lancefield, R. C.: A serological differentiation of specific types of bovine hemolytic streptococci (group B). J. Exp. Med., 59: 441 (1934).

20. Lancefield, R. C., McCarthy, M., and Everly, W. N.: Multiple mouse-protective antibodies directed against group B streptococci. J. Exp. Med., 142: 165 (1975).

21. Laurell, C. B.: Electroimmuno assay. Scand. J. Clin. Lab. Invest., (29, suppl.) 128: 21 (1.972)

22. Lindén, V.: Mouse-protective effect of rabbit anti-R-protein antibodies against group B streptococci type II carrying R-protein. Lack of effect on type III carrying R-protein. Acta Path. Microbiol. Immunol. Scand. (Sect. B.), 91: 145 (1983).

23. Lindén, V.: Immunological aspects of severe neonatal infection with group $B$ streptococci. With special reference to maternal serum antibodies and possible measures for the prevention of neonatal infection. $\mathrm{Ph}, \mathrm{D}$. Thesis, Lund, Sweden 1983.

24. Lindén, V., Christensen, K. K., and Christensen, P.: Heterogeniety of type III group B streptococci in mouse protection tests. Acta Path. Microbiol. Immunol. Scand. (Sect. B.), 90: 267 (1982).

25. Lindén, V., Christensen, K. K., and Christensen, P.: Correlation between low levels of maternal IgG antibodies to R-protein and neonatal septicemia with group B streptococci carrying R-protein. Int. Arch. Allergy Appl. Immunol., 71: $168(1983)$

26. Lindén, V., Christensen, K. K., and Christensen, P.: The occurrence of Rprotein among isolates of group B streptococci from human sources. Acta Path. Microbiol. Immunol. Scand. (Sect. B.), 91: 153 (1983).

27. Patterson, M. J. and Hafeez, A. E. B.: Group B streptococci in human disease. Bacteriol. Rev., 40: 774 (1976).

28. Polin, R. A., Douglas, S. D., Kasper, D. L., and Baker, C. J.: Enzyme-linked immunosorbent assay for measurement of antibody to type III group B streptococci. J. Clin. Microbiol., 15: 991 (1982).

29. Santos, J. I., Shigeoka, A. O., Rote, N. S., and Hill, H. R.: Protective efficacy of a modified immune serum globulin in experimental group B streptococcal infection. J. Pediatr., 99: 873 (1981).

30. Shigeoka, A. O., Hall, R. T., and Hill, H. R.: Strain specificity of opsonins for group B streptococci types II and III. Infect. Immun., 23: 438 (1979).

31. Sidiropoulos, D., Böhme, U., von Muralt, G. Morell, A., and Barandun, S.: Immunglobulinsubstitution bei der Behandlung der neonatalen Sepsis. Schweiz. Med. Wschr., 111: 1649 (1981).

32. Skvaril, F. and Barandun, S.: In vitro characterization of immunoglobulins for intravenous use. In: B. M. Alving and J. S. Finlayson (eds.): Immunoglobulins: characteristics and uses of intravenous preparations. DHHS-Publ. No. (FDA)-80-9005. p. 201 (U.S. Government Printing Office, Washington, 1980).

33. Sramék, J.: Instruction from the WHO collaborating centre for reference and research on streptococci. Institute of Hygiene and Epidemiology, Prague
(1977).

34. Stewardson-Krieger, P. B. Albrandt, K., Nevin, T., Kretschmer, R. R., and Gotoff, S. P.: Perinatal immunity to group B $\beta$-hemolytic Streptococcus type Ia. J. Infect. Dis., 136: 649 (1977).

35. Wilkinson, H. W.: Group B streptococcal infection in humans. Ann. Rev. Microbiol., 32: 41 (1978).

36. Wilkinson, H. W. and Moody, M. D.: Serological relationships of type I antigens of group B streptococci. J. Bacteriol., 97: 629 (1969).

37. Vogel,. L. C., Boyer, K. M., Gadzala, C. A., and Gotoff, S. P.: Prevalence of type-specific group B streptococcal antibody in pregnant women. J. Pediatr., 96: 1047 (1980)

38. Vogel, L. C., Kretschmer, R. R., Padnos, D. M., Kelly, P. D., and Gotoff, S. P.: Protective value of gamma globulin preparations against group B streptococcal infections in chick embryos and mice. Pediatr. Res., 14:788 (1980)

39. Requests for reprints should be addressed to: Dr. Karen K. Christensen, Dept. Obstetrics and Gynecology, University Hospital, S-221 85 LUND, Sweden.

40. We thank Professor Barandun and Drs. Kenny and Matsunaga for critical review of the manuscript. This work was supported by "Allmänna BB Minnesfond", the Expressen Prenatal Research Foundation, the Hezog-EgliStiftung, the Swedish Medical Research Council (grant no. B83-16X-0655901 ) and the Swiss National Science Foundation (grant no. 3.884-0.81).

41. Received for publication March 14, 1983.

42. Accepted for publication August 9, 1983. 